http:/www.journals.zu.edu.eg/journalDisplay.aspx?Journalld=1\&queryType=Master

\title{
EFFECT OF DIFFERENT TYPES OF FERTILIZATION ON MORPHOLOGICAL CHARACTERS AND CHEMICAL CONSTITUENTS OF THREE CULTIVARS OF Hibiscus rosa-sinensis PLANTS
}

\author{
Abd El-Ghafour A. El-Sayed ${ }^{1}$, Mona A. Darwesh ${ }^{1}$, A. Nabih ${ }^{2}$ and Marwa M. Soliman ${ }^{2 *}$ \\ 1. Ornamental Hort. Dept., Fac. Agric., Cairo Univ., Egypt \\ 2. Botanical Gardens Res. Dept., Hort. Res. Inst., Agric. Res. Cent., Giza, Egypt
}

Received: 07/11/2016 ; Accepted: 04/12/2016

\begin{abstract}
The experimental trail was performed throughout two successive seasons (2013 and 2014) with the aim of improving growth and quality of three Hibiscus rosa-sinensis cultivars (red flowers "San Diego", yellow flowers "Butterfly" and orange flowers "Peach Schnapps"). Thus, the effect of three types of fertilization with different levels and some combinations with them, Lithovit (Nano-fertilizer), Diatoms (Algae-fertilizer) and Kristalon (NPK 19:19:19 and micro-elements) on the three cultivars were investigated in both seasons. The results emphasized that Hibiscus cv. San Diego was the best cultivar used for its superiority in producing the tallest plant, the heaviest fresh weight of vegetative growth, the highest number of flowers/plant, and the heaviest fresh weight of roots. Meanwhile Peach Schnapps cv. gave the highest number of leaves/plant, whereas, Butterfly cv. produced the highest number of branches/plant. On the other side, supplying plants with Kristalon alone or combined with fertilizers proved its superiority in improving plant parameters in most cases. The highest records of number of leaves/plant or number of branches/plant were a result of supplying plants with Kristalon at $2 \mathrm{~g} /$ pot. Meanwhile, the heaviest fresh weight of vegetative growth and the highest number of flowers/plant were a result of applying Kristalon at $4 \mathrm{~g} /$ pot. Similarly, the combination of Diatoms at $100 \mathrm{~cm}^{3} /$ pot + Kristalon at $2 \mathrm{~g} /$ pot succeeded in producing the tallest plant and the highest number of branches/plant. Meanwhile, supplying plants with Diatoms at $200 \mathrm{~cm}^{3} /$ pot was the best treatment for producing the heaviest fresh weight of roots. Chemical constituents of the plants were also affected by the different Hibiscus rosa-sinensis cultivars and fertilizer treatments. Peach Schnapps cv. recorded the highest value of N\% in leaves, Butterfly cv. was the best for raising $\mathrm{P}$ and $\mathrm{K} \%$ in leaves. Furthermore, the highest $\mathrm{N} \%$ in leaves was a result of supplying plants with Diatoms at either 100 or $200 \mathrm{~cm}^{3} /$ pot or Kristalon at $4 \mathrm{~g} /$ pot or the combination of Diatoms at 100 $\mathrm{cm}^{3} /$ pot + Kristalon at $2 \mathrm{~g} /$ pot. Moreover, supplying plants with Diatoms at 50 or $200 \mathrm{~cm}^{3} /$ pot or the combination of Diatoms at $100 \mathrm{~cm}^{3} /$ pot + Kristalon at $2 \mathrm{~g} /$ pot caused a clear increment in $\mathrm{P} \%$ in leaves. Meanwhile, treating plants with Lithovit at $0.5,1.0,1.5 \mathrm{~g} / 1$ or Kristalon $4 \mathrm{~g} /$ pot gave the highest values of $\mathrm{K} \%$ in leaves. Additionally, either Hibiscus cv. Peach Schnapps or cv. San Diego were the best cultivars in raising total carbohydrates (\%) in the leaves. Also, treating plants with the combination of Diatoms at $100 \mathrm{~cm}^{3} /$ pot + Kristalon at $2 \mathrm{~g} /$ pot was the best treatment in raising total carbohydrates (\%) in leaves. From the above outlined results it could be recommended to supply plants with Kristalon at 2 or $4 \mathrm{~g} /$ pot or with the combination of Diatoms at $100 \mathrm{~cm}^{3} /$ pot + Kristalon at $2 \mathrm{~g} /$ pot to achieve the hope of producing Hibiscus rosa-sinensis plants with high quality.
\end{abstract}

Key words: Hibiscus rosa-sinensis cultivars, kristalon, diatoms, lithovit.

\section{INTRODUCTION}

Genus Hibiscus includes both annual and perennial herbaceous plants, woody shrubs and small trees. The foliage is dark green when fully developed in the summer. In temperate regions, leaves start growing from late spring. The glossy, green leaves are alternate, simple and

\footnotetext{
*Corresponding author: Tel. : +201062812804

E-mail address: m.soliman85@yahoo.com
} 
ovate to lanceolate, often with a toothed or lobed margin. Hibiscus bell-shaped flowers with stamen spirally arranged along a distinct pistil the dominating characteristic and occur in a rainbow of colors, reaching up to 6" in diameter. Hibiscuses have single or double rows of petals, with either smooth or scalloped edges. The fruit is a dry five-lobed capsule, containing several seeds in each lobe released when the capsule splits open at maturity. Some of the traditional medicinal uses, chemical composition, therapeutic evaluation of Hibiscus rosasinensis, has been carried out by Jadhav et al. (2009). H. rosa sinensis plant as a whole is used in various ailments from centuries. It is an easily available plant for natural remedies for some pharmacological activities of this plant, Sukirti and Prashant (2011), Anil and Ashatha (2012) and Shabana et al. (2013).

H. rosa sinensis, a member of the Malvaceae family, is widely cultivated in the tropics as an ornamental plant for their showy flowers or used as landscape shrubs as mentioned by Ozmen (2010). In the same time, many species of Hibiscus are grown, Hibiscus has also medicinal properties. Flowers of these plants are rich in polyphenols, flavonoids and anthocyanins, Ozmen (2010).

The commercial preparation of Kristalon (a complete fertilizer with macro and micro elements) proved its superiority for improving quality of various plants as mentioned by many scientists. Furcarea foetida cv. Mediopicta affected by all Kristalon and NPK treatments caused considerable increments in plant height, stem diameter, number of leaves/plant, leaf area, fresh and dry weight of leaves and roots, Aze El-Den and Hassan (2009). Cormlets of gladiolus cv. Novalux gave the prevalence of the new corms and cormlets parameters due to applying the mixture of $\mathrm{N}, \mathrm{P}$ and $\mathrm{K}$, whereas Kristalon showed less effect in this regard, (Bazarra et al., 2012). Gladiolus grandiflorus which treated with the low Kristalon level (2 $\mathrm{g} / \mathrm{l}$ ) gave the tallest plants and the highest number of leaves per plant, Mansour et al. (2015).

Furcarea foetida cv. Mediopicta treated with Kristalon and NPK treatments caused considerable increments in leaf content of total carbohydrates, $\mathrm{N}, \mathrm{P}$ and $\mathrm{K}$ percentage, Aze El-Den and Hassan (2009). Philodendron erubescense treated with NPK showed its superiority in increasing chlorophyll a, b and protein (\%) in leaves, (Kheder, 2010). Gladiolus cv. Novalux treated with Kristalon at $2 \mathrm{~g}$ /plant applied as a soil dressing 7 times was the best for elevating $\mathrm{N}$ and $\mathrm{K} \%$ in the new corms, Bazarra et al. (2012).

In tomato plant, a higher content of total chlorophyll was recorded for Lithovit treatment and the highest photosynthesis intensity was observed in tomato treated with Lithovit foliar fertilizer based on $\mathrm{CO}_{2}$. Inside the leaf, Lithovit particles decompose and release among other substances, especially $\mathrm{CO}_{2}$, Beinsan et al. (2014). The effect of four natural fertilizers on the leaf area of seedlings from three tomato hybrids, variants treated with Lithovit and Zoldpajzs the leaves development was not influenced by the genotype. The treatments with fertilizers have shown the highest effect on the development of foliage at the seedlings of Alfred hybrid, Moisă and Berar (2015).

Huysman et al. (2014) stated that accounting for almost one-fifth of the primary production on Earth, the unicellular eukaryotic group of Diatoms plays a key ecological and biogeochemical role in our contemporary oceans. Furthermore, as producers of various lipids and pigments, and characterized by their finely ornamented silica cell wall, Diatoms hold great promise for different industrial fields, including biofuel production, nanotechnology, and pharmaceutics. However, in spite of their major ecological importance and their high commercial value, little is known about the mechanisms that control the diatom life and cell cycle. To date, both microscopic and genomic analyses have revealed that Diatoms exhibit specific and unique mechanisms of cell division compared with those found in the classical model organisms.

Therefore, the present experiment aimed to find out the effect of three types of fertilizers with different levels on three Hibiscus cultivars. 


\section{MATERIALS AND METHODS}

A field experiment was consummated throughout two successive seasons (2013 and 2014) at Ornamental Horticulture Department, Faculty of Agriculture, Cairo University, with the aim of improving growth and development of three Hibiscus rosa-sinensis cultivars. Thus, the effect of three types of fertilizers with different levels, i.e., Lithovit (Nano-fertilizer), Diatoms (Algae-fertilizer) and Kristalon (NPK 19:19:19 and micro-elements) on the three cultivars were used in both seasons.

\section{Materials}

- Three Hibiscus rosa-sinensis cultivars (red flowers "San Diego", yellow flowers "Butterfly" and orange flower "Peach Schnapps") were used.

- Lithovit (nano-fertilizer) is a bio foliar fertilizer. It is natural limestone consisting mainly of $(\mathrm{Ca}, \mathrm{Mg}) \mathrm{CO}_{3}$, which supplies plants with $\mathrm{CO}_{2}$ in much higher concentration than that in the atmosphere and so increases their photosynthesis. It contains furthermore, a big number of micronutrients important for plant physiology.

- Diatoms (Algea fertilizer), Diatoms are algae living in both fresh and salt water. They are unicellular organisms with heavily silica impregnated cell walls.

- Kristalon (DSM Agri. Specialized by Holland) 19:19:19 of N, P and K contained $0.01 \% \mathrm{Cu}, 0.25 \% \mathrm{~B}$ and $0.01 \% \mathrm{Mo}$ was used.

\section{Procedure}

On April $1^{\text {st }}$, rooted cuttings of $(15-20) \mathrm{cm}$ height for the three Hibiscus rosa-sinensis cvs were planted in pots (one plant/each). Physical and chemical analyses of the used soil are presented in Table 1. Thereafter, the plants left to grow under open field condition. Fertilizer treatments were applied after one month from planting and then at 15 days interval for four times. Kristalon was applied at 1,2 and $4 \mathrm{~g}$ /plant, Diatoms applied at 50,100 and $200 \mathrm{~cm}^{3}$ /plant as soil dressing, whereas Lithovit was applied at $0.5,1.0$ and $1.5 \mathrm{~g} / 1$ was dissolved in tap water and applied as a foliar spray on the plant foliage until run off point. Control (untreated plants) were sprayed with water only. Besides, the application of the combination of Diatoms $100 \mathrm{~cm}^{3} /$ plant + Kristalon $2 \mathrm{~g} /$ plant and Diatoms $100 \mathrm{~cm}^{3} /$ plant + Lithovit $1.0 \mathrm{gm} / 1$.

The layout of the experiment was Factorial experiment in Complete Randomized Block Design, with 12 treatments with three replications, every replicate contains three plants. The main plots were cultivars while the sub-plots were fertilization treatments.

After six months from planting, morphological characters of the plants were recorded for the followings: Plant height $(\mathrm{cm})$, number of leaves / plant, number of branches / plant, number of flowers/plant, fresh weight of vegetative growth (g) and Fresh weight of roots (g). In addition, data in the second season including chemical composition: Total carbohydrates content in leaves $(\% \mathrm{DW})$, total nitrogen contents in leaves (\% DW), total phosphorus contents in leaves (\% DW) and potassium contents in leaves ( $\%$ DW).

\section{Determination of Dry Matter}

The samples were dried in an electric oven at $70^{\circ} \mathrm{C}$ till a constant weight then it were ground in a grinding mill to fine powder. The chemical analysis was carried out in the dried leaves as follows:

- Total carbohydrates in dried leaves were determined according to Herbert et al. (1971).

- Elements extraction was made using a known weight of the dried samples $(0.20 \mathrm{~g})$. The wet digestion procedure was performed as described by Piper (1947).

- Nitrogen contents were determined by the modified micro-Kjeldahl method as described by Pregle (1945).

- Phosphorus contents were determined as described by Troug and Meyer (1939).

- Potassium content was determined by using Pye Unicam model Sp 1900 Atomic Absorption, Flame emission spectrophotometer with a boiling air-acetylene burner and recorded read out. 
Table 1. Physical and chemical characteristics of the soil used for growing Hibiscus rosa-sinensis cultivars during the 2013 and 2014 seasons

\begin{tabular}{lll}
\hline Parameter & $\mathbf{2 0 1 3}$ & $\mathbf{2 0 1 4}$ \\
\hline Physical characteristics & 37.1 & \\
Clay (\%) & 36.2 & 40.5 \\
Silt (\%) & 22.9 & 35.1 \\
Fine sand (\%) & 3.80 & 21.0 \\
Coarse sand (\%) & Clay & 3.40 \\
Texture & 8.03 & Clay \\
pH & 1.65 & 7.88 \\
ECdS/m ${ }^{-1}$ & 1.50 & 1.63 \\
Organic matter & & 1.70 \\
Chemical characteristics & & \\
Soluble cations(meq/1) & 7.00 & \\
Ca++ & 2.87 & 7.22 \\
$\mathrm{Mg}^{++}$ & 0.27 & 2.98 \\
$\mathrm{~K}^{+}$ & 5.88 & 0.33 \\
$\mathrm{Na}+$ & & 6.22 \\
Soluble anions (meq/1) & 3.60 & 3.50 \\
$\mathrm{Cl}^{-}$ & 2.38 & 2.45 \\
$\mathrm{SO}{ }_{4}^{-}$ & 27.0 & 30.1 \\
$\mathrm{Available} \mathrm{N} \mathrm{(ppm)}$ & 20.5 & 22.5 \\
Available P (ppm) & &
\end{tabular}

\section{Statistical Analysis}

The data on vegetative growth in the two seasons were statistically analyzed as described by Snedecor and Cochran (1972). Means of all characters were compared by LSD test at 0.05 level of significance.

\section{RESULTS AND DISCUSSION}

\section{Plant Height (cm)}

It is clear from the data presented in Table 2 that Hibiscus cv. San Diego gave the tallest plant in both seasons, registering 71.37 and $70.79 \mathrm{~cm}$ in both seasons, respectively, followed with significant differences by Hibiscus cv.
"Peach Schnapps" in the two seasons, scoring 58.66 and $58.56 \mathrm{~cm}$., respectively. In contrast the least values were obtained by Hibiscus cv. "Butterfly", registering only 50.65 and $50.92 \mathrm{~cm}$ in the first and second seasons, respectively. On the other hand, all fertilization treatments caused a clear increment in plant height, with significant differences in most cases in the two seasons. However, using the combination of Diatoms at $100 \mathrm{~cm} 3 /$ pot + Kristalon at $2 \mathrm{~g} /$ pot was the most effective treatment, which gave the tallest plant comparing with unfertilized plants (control) and other treatments used. It gave the values of 72.72 and $72.66 \mathrm{~cm}$. against 49.11 and $48.55 \mathrm{~cm}$. for control in the first and second seasons, respectively. The second rank for 
Table 2. Effect of different Hibiscus rosa-sinensis cultivars, fertilizer treatments and their interaction on plant height $(\mathrm{cm})$ in two seasons

\begin{tabular}{|c|c|c|c|c|c|c|c|c|}
\hline \multirow{2}{*}{$\begin{array}{l}\text { Season } \\
\text { Cultivars (a) } \\
\text { Treatment (b) }\end{array}$} & \multicolumn{4}{|c|}{ First season (2013) } & \multicolumn{4}{|c|}{ Second season (2014) } \\
\hline & $\begin{array}{c}\text { Red (San } \\
\text { Diego) }\end{array}$ & $\begin{array}{c}\text { Yellow } \\
\text { (Butterfly) }\end{array}$ & $\begin{array}{c}\text { Orange } \\
\text { (Peach } \\
\text { Schnapps) }\end{array}$ & $\begin{array}{c}\text { Mean } \\
\text { b }\end{array}$ & $\begin{array}{c}\text { Red } \\
\text { (San } \\
\text { Diego) }\end{array}$ & $\begin{array}{c}\text { Yellow } \\
\text { (Butterfly) }\end{array}$ & $\begin{array}{c}\text { Orange } \\
\text { (Peach } \\
\text { Schnapps) }\end{array}$ & $\begin{array}{c}\text { Mean } \\
\text { b }\end{array}$ \\
\hline$\overline{\text { Control }}$ & 63.33 & 38.16 & 45.83 & 49.11 & 60.33 & 38.67 & 45.83 & 48.55 \\
\hline Kristalon $1 \mathrm{~g}$ & 71.66 & 51.00 & 59.83 & 60.83 & 66.50 & 50.50 & 56.83 & 57.94 \\
\hline Kristalon 2 g & 76.00 & 55.66 & 61.50 & 64.38 & 73.00 & 52.67 & 58.17 & 61.28 \\
\hline Kristalon 4 g & 81.00 & 61.00 & 63.50 & 68.50 & 79.83 & 55.67 & 61.33 & 65.61 \\
\hline Diatoms $50 \mathrm{~cm}^{3}$ & 65.50 & 47.50 & 50.00 & 54.33 & 63.00 & 52.00 & 49.67 & 54.89 \\
\hline Diatoms $100 \mathrm{~cm}^{3}$ & 66.00 & 50.83 & 54.16 & 57.00 & 66.17 & 54.83 & 51.50 & 57.50 \\
\hline Diatoms $200 \mathrm{~cm}^{3}$ & 75.83 & 53.50 & 59.50 & 62.94 & 69.67 & 55.66 & 59.00 & 61.44 \\
\hline Lithovit $0.5 \mathrm{~g} / \mathrm{l}$ & 64.83 & 44.83 & 48.00 & 52.55 & 63.83 & 40.16 & 52.50 & 52.16 \\
\hline Lithovit $1.0 \mathrm{~g} / \mathrm{l}$ & 69.16 & 45.33 & 56.66 & 57.05 & 64.33 & 49.16 & 58.33 & 57.27 \\
\hline Lithovit $1.5 \mathrm{~g} / \mathrm{l}$ & 71.83 & 51.50 & 60.33 & 61.22 & 69.50 & 52.33 & 65.50 & 62.44 \\
\hline Diatoms $100 \mathrm{~cm}^{3}+$ Kristalon $2 \mathrm{~g}$ & 82.66 & 61.83 & 73.66 & 72.72 & 88.33 & 57.33 & 72.33 & 72.66 \\
\hline Diatoms $100 \mathrm{~cm}^{3}+$ Lithovit $1.0 \mathrm{~g} / \mathrm{l}$ & 68.66 & 46.66 & 71.00 & 62.11 & 85.00 & 52.00 & 71.67 & 69.55 \\
\hline Mean a & 71.37 & 50.65 & 58.66 & & 70.79 & 50.92 & 58.56 & \\
\hline \multicolumn{9}{|l|}{ LSD at 0.05 for } \\
\hline Cultivars (a) & \multicolumn{4}{|c|}{3.22} & \multicolumn{4}{|c|}{4.09} \\
\hline Treatment (b) & \multicolumn{4}{|c|}{6.45} & \multicolumn{4}{|c|}{8.17} \\
\hline Interaction $(\mathbf{a} \times \mathbf{b})$ & \multicolumn{4}{|c|}{11.17} & \multicolumn{4}{|c|}{14.16} \\
\hline
\end{tabular}

elevating the same parameter belonged to plants which received Kristalon at $4 \mathrm{~g} /$ pot giving 68.50 and $65.61 \mathrm{~cm}$. in both seasons, respectively. In contrast, the least values were assigned to plants which treated with Lithovit at $0.5 \mathrm{~g} / 1$ as the values reached only 52.55 and $52.16 \mathrm{~cm}$. in both seasons, respectively. Concerning the interactions, receiving plants of Hibiscus cv. San Diego combined with diatoms at $100 \mathrm{~cm}^{3} /$ pot + kristalon at $2 \mathrm{~g} /$ pot gave the highest values in both seasons, registering 82.66 and $88.33 \mathrm{~cm}$ in the two seasons, respectively. In contrast the least beneficial effect for improving such trait was concomitant to plants of Hibiscus cv. "Butterfly" received either lithovit at $0.5 \mathrm{~g} / \mathrm{l}$ in both seasons, scoring only 44.83 and $40.16 \mathrm{~cm}$, respectively.

\section{Number of Leaves/Plant}

Marked influence on number of leaves/plant was detected due to using different Hibiscus cultivars (Table 3). Hibiscus cv. "Peach Schnapps" had the highest number of leaves/ plant, followed with significant difference by that obtained from Hibiscus cv. San Diego, then came that of Hibiscus cv. "Butterfly" without significant differences with occupying the third rank in this regard. They registered 65.50, 51.38 and 49.59 in the first season and 66.09, 54.76 and 51.91 in the second one, respectively. Clear increment in number of leaves/plant comparing with control was observed, with significant effect in most cases due to supplying plants with the different fertilization treatments in both seasons. In this concern, supplying plants with 
Table 3. Effect of different Hibiscus rosa-sinensis cultivars, fertilizer treatments and their interaction on number of leaves/plant in two seasons

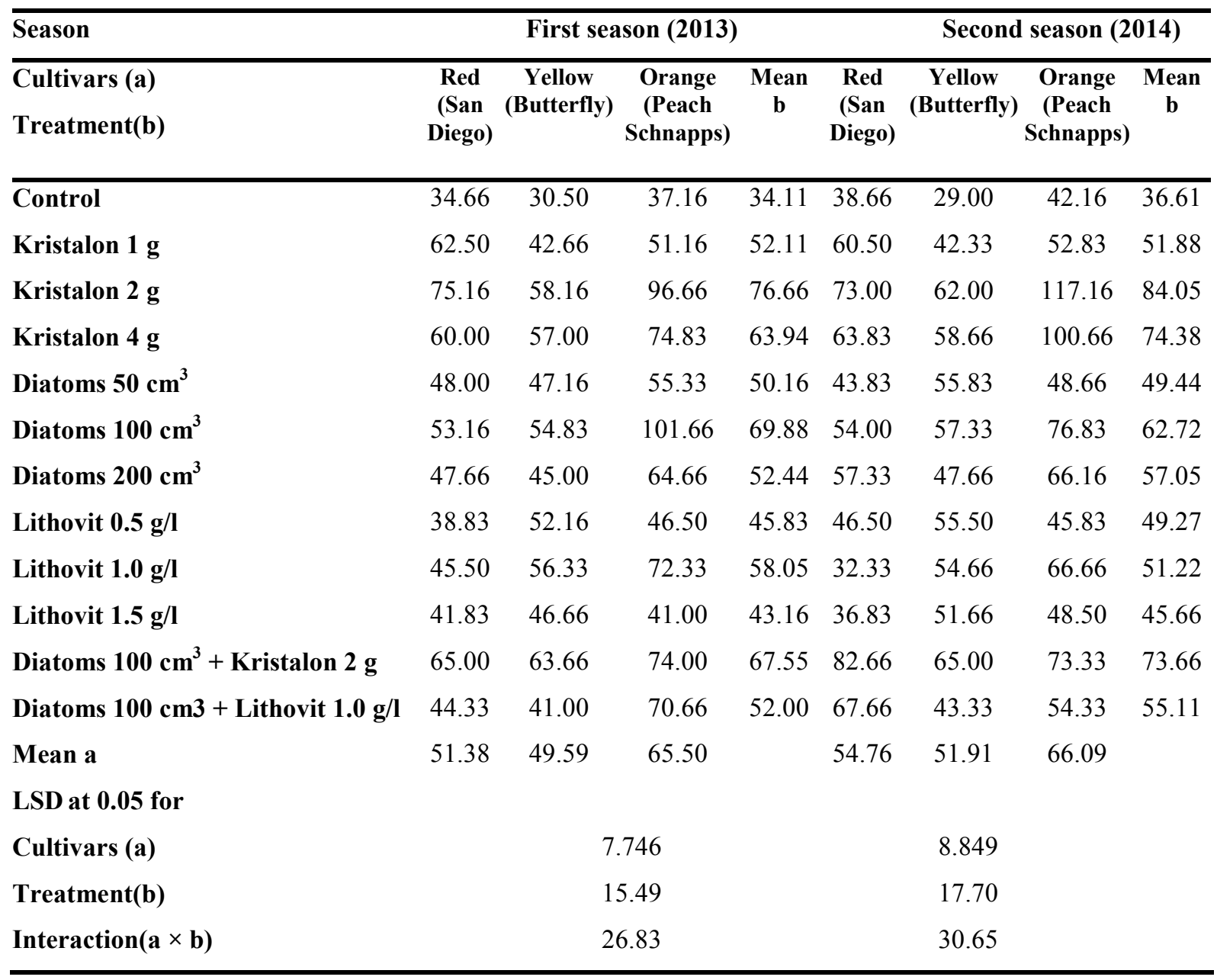

Kristalon treatment at $2 \mathrm{~g} /$ pot was the best treatment used in both seasons in raising number of leaves/plant (76.66 and 84.05, respectively), followed in the second degree by plants which received Diatoms at $100 \mathrm{~cm}^{3} /$ pot in the first season and those which supplied with Kristalon at $4 \mathrm{~g} /$ pot in the second one, registering 69.88 and 74.38 in the first and second seasons, respectively. The third position, for rising the same parameter belonged to plants which treated with the combination of Diatoms at $100 \mathrm{~cm}^{3} /$ pot + Kristalon at $2 \mathrm{~g} /$ pot in both seasons, giving 67.55 and 73.66, respectively. The interaction, cleared that the highest records in number of leaves/plant resulted from supplying plants of Hibiscus cv. "Peach Schnapps" with Diatoms at $100 \mathrm{~cm}^{3} /$ pot in the first season and those of the same cultivar which received kristalon at $2 \mathrm{~g} / \mathrm{pot}$ in the second one, scoring 101.66 and 117.16 in the first and second season, respectively. In contrast, the least beneficial effect in raising number of leaves/plant resulted from Hibiscus plants of cv. "Peach Schnapps" and San Diego which received Lithovit at $1.5 \mathrm{~g} / 1$ and the combination of diatoms at $100 \mathrm{~cm}^{3} /$ pot + Lithovit at $1.0 \mathrm{~g} / 1$ for "Butterfly" cv. In the first season, recording 41.00, 41.83 and 41.00, respectively. Meanwhile, the least values of the effect of fertilization in the second season was obtained due to treating plants of cv. San Diego with lithovit at $1.0 \mathrm{~g} / 1$ (32.33).

\section{Number of Branches/Plant}

Marked influences were observed in number of branches/plant of the different Hibiscus cultivars used in both seasons (Table 4). Hibiscus cv. "Butterfly" gave the highest number of branches/plant in the two seasons, giving 19.55 
Table 4. Effect of different Hibiscus rosa-sinensis cultivars, fertilizer treatments and their interaction on number of branches/plant in two seasons

\begin{tabular}{|c|c|c|c|c|c|c|c|c|}
\hline \multirow{2}{*}{$\begin{array}{l}\text { Season } \\
\text { Cultivars (a) } \\
\text { Treatment (b) }\end{array}$} & \multirow[b]{2}{*}{$\begin{array}{c}\text { Red (San } \\
\text { Diego) }\end{array}$} & \multicolumn{3}{|c|}{ First season (2013) } & \multicolumn{4}{|c|}{ Second season (2014) } \\
\hline & & $\begin{array}{c}\text { Yellow } \\
\text { (Butterfly) }\end{array}$ & $\begin{array}{c}\text { Orange } \\
\text { (Peach } \\
\text { Schnapps) }\end{array}$ & $\begin{array}{c}\text { Mean } \\
\text { b }\end{array}$ & $\begin{array}{c}\text { Red } \\
\text { (San } \\
\text { Diego) }\end{array}$ & $\begin{array}{c}\text { Yellow } \\
\text { (Butterfly) }\end{array}$ & $\begin{array}{c}\text { Orange } \\
\text { (Peach } \\
\text { Schnapps) }\end{array}$ & $\begin{array}{c}\text { Mean } \\
\text { b }\end{array}$ \\
\hline$\overline{\text { Control }}$ & 7.83 & 13.66 & 8.66 & 10.05 & 6.66 & 14.00 & 9.00 & 9.88 \\
\hline Kristalon $1 \mathrm{~g}$ & 9.00 & 20.83 & 13.16 & 14.33 & 9.83 & 20.83 & 15.00 & 15.22 \\
\hline Kristalon $2 \mathrm{~g}$ & 12.16 & 27.50 & 25.66 & 21.77 & 12.00 & 24.16 & 21.83 & 19.33 \\
\hline Kristalon $4 \mathrm{~g}$ & 10.33 & 18.50 & 24.16 & 17.66 & 10.50 & 18.66 & 19.83 & 16.33 \\
\hline Diatoms $50 \mathrm{~cm}^{3}$ & 8.16 & 15.66 & 13.66 & 12.50 & 7.16 & 17.00 & 14.00 & 12.72 \\
\hline Diatoms $100 \mathrm{~cm}^{3}$ & 10.16 & 17.66 & 16.16 & 14.66 & 10.00 & 19.16 & 14.33 & 14.50 \\
\hline Diatoms $200 \mathrm{~cm}^{3}$ & 8.66 & 16.00 & 12.83 & 12.50 & 9.33 & 17.33 & 15.00 & 13.88 \\
\hline Lithovit $0.5 \mathrm{~g} / \mathrm{l}$ & 8.33 & 18.16 & 11.16 & 12.55 & 7.16 & 18.33 & 12.00 & 12.50 \\
\hline Lithovit $1.0 \mathrm{~g} / \mathrm{l}$ & 9.33 & 19.50 & 15.83 & 14.88 & 8.16 & 19.83 & 14.16 & 14.05 \\
\hline Lithovit $1.5 \mathrm{~g} / \mathrm{l}$ & 9.33 & 15.83 & 13.16 & 12.77 & 7.00 & 16.33 & 12.00 & 11.77 \\
\hline Diatoms $100 \mathrm{~cm}^{3}+$ Kristalon $2 \mathrm{~g}$ & 14.33 & 28.00 & 24.66 & 22.33 & 13.33 & 25.66 & 23.66 & 20.88 \\
\hline Diatoms $100 \mathrm{~cm}^{3}+$ Lithovit $1.0 \mathrm{~g} / \mathrm{l}$ & 10.00 & 23.33 & 18.33 & 17.22 & 10.00 & 21.66 & 16.33 & 16.00 \\
\hline Mean a & 9.80 & 19.55 & 16.45 & & 9.26 & 19.41 & 15.59 & \\
\hline \multicolumn{9}{|l|}{ LSD at 0.05 for } \\
\hline Cultivars (a) & \multicolumn{4}{|c|}{1.52} & \multicolumn{4}{|c|}{1.41} \\
\hline Treatment (b) & \multicolumn{4}{|c|}{3.03} & \multicolumn{4}{|c|}{2.82} \\
\hline Interaction $(\mathbf{a} \times \mathbf{b})$ & \multicolumn{4}{|c|}{5.25} & \multicolumn{4}{|c|}{4.88} \\
\hline
\end{tabular}

and 19.41, respectively. Whereas, Hibiscus cv. San Diego gave the lowest means in the two seasons (9.80 and 9.26, respectively). The other cultivar ("Peach Schnapps") gave an intermediate effect in this regard (16.45 and 15.59 in the first and second seasons, respectively. Generally, it could be concluded from data averaged in Table 4 that all fertilization treatments increased number of branches/plant comparing with control, with significant effects in most cases. In this connection, supplying plants with either Kristalon at $2 \mathrm{~g} /$ pot or with the combination of Diatoms at $100 \mathrm{~cm}^{3} /$ pot gave the highest number of branches/plant, giving 21.77 and 22.33 in the first season and 19.33 and 20.88 in the second one, respectively. On the contrary, the least beneficial effect for raising such trait was a result of treating plants with Diatoms at $50 \mathrm{~cm}^{3}$ pot, Diatoms at $200 \mathrm{~cm}^{3} /$ pot, Lithovit at $0.5 \mathrm{~g} / 1$ and Lithovit at $1.5 \mathrm{~g} / 1$ in the two seasons, registering $12.50,12.50,12.55$ and 12.77 in the first season, 12.72, 13.88, 12.50 and 11.77 in the second one, respectively. Considerable variations in the recorded data were noticed due to the interaction between the different Hibiscus cultivars and fertilization treatments. In the regard receiving plants of Hibiscus cv. "butterfly" with the combination of diatoms at $100 \mathrm{~cm}^{3} /$ pot + kristalon at $2 \mathrm{~g} /$ pot and kristalon at $2 \mathrm{~g} / \mathrm{pot}$ gave the highest values in the two seasons, scoring 28.00 and 27.50 in the first season and 25.66 and 24.16 in the second one. In the contrast the least beneficial effect for improving such trait was assigned to plants of Hibiscus cv. San Diego treated with either Diatoms at $50 \mathrm{~cm} 3 /$ pot or with Lithovit at 0.5 
$\mathrm{g} / \mathrm{l}$, in both seasons, beside plants which received Lithovite at $1.5 \mathrm{~g} / 1$ in the second season, scoring only 8.16 and 8.33 in the first season and 7.16, 7.16 and 7.00 in the second one, respectively. The other treatments gave an intermediate effect in this concern.

\section{Number of Flowers/Plant}

Marked influences in number of flowers/ plant were observed due to using the different Hibiscus cultivars in plantation (Table 5). San Diego cv. gave the highest values in both seasons, followed with significant difference by "Peach Schnapps" cv., with occupying the second rank, then came the effect of "Butterfly" cv., which produced the lowest records in the two seasons. They registered $8.99,4.90$ and 3.10 in the first season and 8.10, 4.90 and 3.70 in the second one, respectively. The significantly highest values of number of flowers/plant were obtained by plants which treated with Diatoms $100 \mathrm{~cm}^{3} /$ pot + Kristalon at $2 \mathrm{~g} /$ pot followed without significant differences with plants supplied with Kristalon at $4 \mathrm{~g} /$ pot in the first season. Meanwhile, supplying plants, with Diatoms $100 \mathrm{~cm}^{3} /$ pot + Kristalon at $2 \mathrm{~g} /$ pot or with Diatoms $200 \mathrm{~cm}^{3} /$ pot gave the highest values in the second season. These treatments registered 7.0 and 6.7 in the first season and 6.8 and 6.4 in the second one, respectively. The interaction, cleared that the highest records in number of flowers/plant resulted from supplying Hibiscus cv. "San Diego" plants with Diatoms $100 \mathrm{~cm}^{3} /$ pot + Kristalon at $2 \mathrm{~g} /$ pot and Diatoms at $200 \mathrm{~cm}^{3} /$ pot in the first season. giving 10.0 and 9.7. In the second season, treated plants with Diatoms at $200 \mathrm{~cm} 3 /$ pot and Kristalon at $4 \mathrm{~g} /$ pot of the same cultivar gave 9.3 and 9.3, respectively. Whereas, "Butterfly" cv. Plants combined with non-fertilizer treatment gave the lowest number of flowers in the two seasons.

\section{Fresh Weight of Vegetative Growth (g/plant)}

The significantly highest record of fresh weight of vegetative growth was observed in San Diego cv., followed with a significant difference by plants of either "Butterfly" or "Peach Schnapps" cv. which occupied the second category in both seasons. They gave $113.31,94.91$ and $89.14(\mathrm{~g})$ in the first season and $113.07,85.83$ and $92.05(\mathrm{~g})$ in the second one, respectively, Table (6). Marked influences in fresh weight of vegetative growth were observed due to supplying plants with different types and levels of fertilizer treatments in both seasons. In this connection, treating plants with Diatoms $100 \mathrm{~cm}^{3} /$ pot + Kristalon $2 \mathrm{~g} /$ pot in both seasons as well as with applying Kristalon (4 g/ pot) in the first season and Diatoms at $200 \mathrm{~cm}^{3} /$ pot in the second one proved their superiority in producing the heaviest fresh weight of vegetative growth, registering 137.83 and 128.19 in the first season and 142.50 and $120.30 \mathrm{~g}$, respectively, against 59.89 and 61.43 (g) of control means in the two seasons, respectively. In contrast, the least benefits for improving such trait was assigned to plants which received Lithovit at 0.5 $\mathrm{g} / \mathrm{l}$ in both seasons, giving only 76.12 and 69.49 (g), respectively. The interaction, cleared that the highest records from supplying plants of Hibiscus cv. "San Diego" with Diatoms at 100 $\mathrm{cm}^{3} /$ pot + Kristalon $(2 \mathrm{~g} /$ pot $)$ in the first season and Hibiscus cv. "Peach Schnapps" Diatoms at $100 \mathrm{~cm} 3 /$ pot + Kristalon $(2 \mathrm{~g} / \mathrm{pot})$ in the second season, scoring 169.61 and 157.10 in the first and second season, respectively. Whereas control treatments combined with "Peach Schnapps" gave the lowest weight of vegetative growth in both seasons.

\section{Fresh Weight of Roots (g/plant)}

Considerable variations in fresh weight of roots were noticed as a result of using the different Hibiscus cvs. in plantation (Table 7). San Diego cv. Obtained the heaviest fresh weight of roots, with occupying the first rank (105.08 and 93.88 (g/plant) in the first and second seasons, respectively). Whereas "Butterfly" cv. gave the lowest fresh weight of roots valued 54.40 and $47.95 \mathrm{~g}$ in the first and second seasons, respectively. Supplying plants with Diatoms at $200 \mathrm{~cm}^{3} /$ pot proved its superiority in raising fresh weight of roots in the first season and treating plants with the combination of Diatoms at $100 \mathrm{~cm} 3 /$ pot + Kristalon at $2 \mathrm{~g} /$ pot in the second one, giving 120.20 and $108.78 \mathrm{~g}$, respectivly. Meanwhile, treating plants with the combination of Diatoms at $100 \mathrm{~cm}^{3} /$ pot + Kristalon at $2 \mathrm{~g} /$ pot in the first season and with Diatoms at $200 \mathrm{~cm} 3 /$ pot gave the second rank in improving fresh weight of roots in the second season, registering 108.20 
Table 5. Effect of different Hibiscus rosa-sinensis cultivars, fertilizer treatments and their interaction on number of flowers per plant in two seasons

\begin{tabular}{|c|c|c|c|c|c|c|c|c|}
\hline \multirow{2}{*}{$\begin{array}{l}\text { Season } \\
\text { Cultivars (a) } \\
\text { Treatment (b) }\end{array}$} & \multicolumn{5}{|c|}{ First season (2013) } & \multicolumn{3}{|c|}{ Second season (2014) } \\
\hline & $\begin{array}{c}\text { Red } \\
\text { (San } \\
\text { Diego) } \\
\end{array}$ & $\begin{array}{c}\begin{array}{c}\text { Yellow } \\
\text { (Butterfly) }\end{array} \\
\end{array}$ & 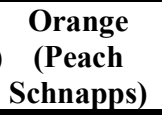 & $\begin{array}{c}\text { Mean } \\
\text { b }\end{array}$ & $\begin{array}{c}\text { Red } \\
\text { (San } \\
\text { Diego) } \\
\end{array}$ & $\begin{array}{c}\text { Yellow } \\
\text { (Butterfly) }\end{array}$ & $\begin{array}{c}\begin{array}{c}\text { Orange } \\
\text { (Peach } \\
\text { Schnapps) }\end{array} \\
\end{array}$ & $\begin{array}{c}\text { Mean } \\
\text { b }\end{array}$ \\
\hline Control & 6.3 & 1.7 & 3.3 & 3.8 & 7.3 & 2.0 & 3.3 & 4.2 \\
\hline Kristalon 1 g & 7.0 & 2.7 & 4.3 & 4.7 & 7.7 & 2.3 & 3.7 & 4.6 \\
\hline Kristalon 2 g & 9.0 & 3.7 & 5.0 & 5.9 & 9.0 & 2.7 & 4.3 & 5.3 \\
\hline Kristalon $4 \mathrm{~g}$ & 9.3 & 4.3 & 6.3 & 6.7 & 9.3 & 3.0 & 4.7 & 5.7 \\
\hline Diatoms $50 \mathrm{~cm}^{3}$ & 7.0 & 2.3 & 4.0 & 4.4 & 6.3 & 3.3 & 5.3 & 5.0 \\
\hline Diatoms $100 \mathrm{~cm}^{3}$ & 8.3 & 2.7 & 4.3 & 5.1 & 8.3 & 3.7 & 5.7 & 5.9 \\
\hline Diatoms $200 \mathrm{~cm}^{3}$ & 9.7 & 3.0 & 5.3 & 6.0 & 9.3 & 4.0 & 6.0 & 6.4 \\
\hline Lithovit $0.5 \mathrm{~g} / \mathrm{l}$ & 6.7 & 2.7 & 4.0 & 4.4 & 6.7 & 3.7 & 3.3 & 4.6 \\
\hline Lithovit $1.0 \mathrm{~g} / \mathrm{l}$ & 7.0 & 2.7 & 5.0 & 4.9 & 7.0 & 4.3 & 6.0 & 5.8 \\
\hline Lithovit $1.5 \mathrm{~g} / \mathrm{l}$ & 7.3 & 3.3 & 5.7 & 5.4 & 8.0 & 5.0 & 5.7 & 6.2 \\
\hline Diatoms $100 \mathrm{~cm}^{3}+$ Kristalon $2 \mathrm{~g}$ & 10.0 & 4.7 & 6.3 & 7.0 & 9.0 & 5.3 & 6.0 & 6.8 \\
\hline Diatoms $100 \mathrm{~cm}^{3}+$ Lithovit $1.0 \mathrm{~g} / \mathrm{l}$ & 8.7 & 4.0 & 5.7 & 6.1 & 8.7 & 4.7 & 4.7 & 6.0 \\
\hline $\begin{array}{l}\text { Mean a } \\
\text { LSD at } 0.05 \text { for }\end{array}$ & 8.00 & 3.10 & 4.90 & & 8.10 & 3.70 & 4.90 & \\
\hline Cultivars (a) & & & 0.34 & & & & 0.48 & \\
\hline Treatment (b) & & & 0.68 & & & & 0.96 & \\
\hline Interaction $(\mathbf{a} \times \mathbf{b})$ & & & 1.19 & & & & 1.67 & \\
\hline
\end{tabular}

Table 6. Effect of different Hibiscus rosa-sinensis cultivars, fertilizer treatments and their interaction on fresh weight of vegetative growth (g/plant) in two seasons

\begin{tabular}{|c|c|c|c|c|c|c|c|c|}
\hline Season & & First s & $\overline{\operatorname{season}(20}$ & & & Second & d seas & $\overline{2014)}$ \\
\hline $\begin{array}{l}\text { Cultivars (a) } \\
\text { Treatment(b) }\end{array}$ & $\begin{array}{c}\text { Red } \\
\text { (San } \\
\text { Diego) } \\
\end{array}$ & $\begin{array}{c}\text { Yellow } \\
\text { (Butterfly) }\end{array}$ & $\begin{array}{c}\begin{array}{c}\text { Orange } \\
\text { (Peach } \\
\text { Schnapps) }\end{array} \\
\end{array}$ & $\begin{array}{c}\text { Mean } \\
\text { b }\end{array}$ & $\begin{array}{c}\text { Red } \\
\text { (San } \\
\text { Diego) } \\
\end{array}$ & $\begin{array}{c}\text { Yellow } \\
\text { (Butterfly) }\end{array}$ & $\begin{array}{c}\text { Orange } \\
\text { (Peach } \\
\text { Schnapps) }\end{array}$ & $\begin{array}{c}\text { Mean } \\
b\end{array}$ \\
\hline Control & 80.95 & 64.40 & 34.33 & 59.89 & 81.82 & 59.96 & 42.49 & 61.43 \\
\hline Kristalon $1 \mathrm{~g}$ & 114.79 & 92.72 & 65.25 & 90.92 & 123.47 & 90.95 & 61.66 & 92.03 \\
\hline Kristalon $2 \mathrm{~g}$ & 130.76 & 100.05 & 81.60 & 104.14 & 127.05 & 91.29 & 89.28 & 102.54 \\
\hline Kristalon $4 \mathrm{~g}$ & 165.73 & 120.70 & 98.13 & 128.19 & 149.78 & 100.34 & 108.52 & 119.55 \\
\hline Diatoms $50 \mathrm{~cm}^{3}$ & 90.23 & 92.18 & 72.23 & 84.88 & 93.90 & 87.85 & 70.07 & 83.94 \\
\hline Diatoms $100 \mathrm{~cm}^{3}$ & 97.94 & 94.38 & 116.93 & 103.08 & 114.04 & 99.77 & 100.88 & 104.90 \\
\hline Diatoms $200 \mathrm{~cm}^{3}$ & 110.55 & 102.46 & 131.03 & 114.68 & 121.25 & 113.58 & 126.08 & 120.30 \\
\hline Lithovit 0.5 g/l & 84.25 & 78.67 & 65.46 & 76.12 & 87.75 & 62.11 & 58.60 & 69.49 \\
\hline Lithovit $1.0 \mathrm{~g} / \mathrm{l}$ & 88.22 & 85.24 & 75.99 & 83.15 & 94.83 & 68.98 & 78.72 & 80.85 \\
\hline Lithovit $1.5 \mathrm{~g} / \mathrm{l}$ & 100.69 & 93.05 & 109.36 & 101.03 & 101.32 & 71.72 & 92.81 & 88.62 \\
\hline Diatoms $100 \mathrm{~cm}^{3}+$ Kristalon $2 \mathrm{~g}$ & 169.61 & 122.60 & 121.28 & 137.83 & 147.92 & 104.47 & 175.10 & 142.50 \\
\hline Diatoms $100 \mathrm{~cm}^{3}+$ Lithovit $1.0 \mathrm{~g} / \mathrm{l}$ & 125.94 & 92.44 & 98.03 & 105.47 & 113.73 & 78.97 & 100.412 & 97.71 \\
\hline $\begin{array}{l}\text { Mean a } \\
\text { LSD at } 0.05 \text { for }\end{array}$ & 113.31 & 94.91 & 89.14 & & 113.07 & 85.83 & 92.05 & \\
\hline $\begin{array}{l}\text { Cultivars (a) } \\
\text { Treatment(b) }\end{array}$ & & & $\begin{array}{c}8.72 \\
17.44\end{array}$ & & & & $\begin{array}{l}10.17 \\
20.35\end{array}$ & \\
\hline Interaction $(\mathbf{a} \times \mathbf{b})$ & & & 30.21 & & & & 35.25 & \\
\hline
\end{tabular}


Table 7. Effect of different Hibiscus rosa-sinensis cultivars, fertilizer treatments and their interaction on fresh weight of root (g/plant) in two seasons

\begin{tabular}{|c|c|c|c|c|c|c|c|c|}
\hline \multirow{2}{*}{$\begin{array}{l}\text { Season } \\
\text { Cultivars (a) } \\
\text { Treatment (b) }\end{array}$} & \multicolumn{5}{|c|}{ First season (2013) } & \multicolumn{3}{|c|}{ Second season (2014) } \\
\hline & $\begin{array}{c}\text { Red } \\
\text { (San } \\
\text { Diego) }\end{array}$ & $\begin{array}{c}\text { Yellow } \\
\text { (Butterfly) }\end{array}$ & $\begin{array}{c}\text { Orange } \\
\text { (Peach } \\
\text { Schnapps) }\end{array}$ & $\begin{array}{c}\text { Mean } \\
\text { b }\end{array}$ & $\begin{array}{c}\text { Red } \\
\text { (San } \\
\text { Diego) }\end{array}$ & $\begin{array}{c}\text { Yellow } \\
\text { (Butterfly) }\end{array}$ & $\begin{array}{c}\text { Orange } \\
\text { (Peach } \\
\text { Schnapps) }\end{array}$ & $\begin{array}{c}\text { Mean } \\
\text { b }\end{array}$ \\
\hline Control & 68.12 & 21.25 & 29.06 & 39.48 & 67.39 & 16.46 & 39.17 & 41.01 \\
\hline Kristalon $1 \mathrm{~g}$ & 84.81 & 31.60 & 51.55 & 55.99 & 96.98 & 26.92 & 45.95 & 56.62 \\
\hline Kristalon 2 g & 124.62 & 42.62 & 54.71 & 73.98 & 102.37 & 38.67 & 46.41 & 62.48 \\
\hline Kristalon $4 \mathrm{~g}$ & 134.06 & 58.81 & 68.95 & 87.27 & 112.30 & 51.17 & 64.75 & 76.07 \\
\hline Diatoms $50 \mathrm{~cm}^{3}$ & 83.40 & 49.05 & 59.72 & 64.06 & 87.12 & 40.46 & 64.37 & 63.98 \\
\hline Diatoms $100 \mathrm{~cm}^{3}$ & 131.48 & 76.65 & 89.07 & 99.07 & 101.34 & 53.18 & 88.40 & 80.97 \\
\hline Diatoms $200 \mathrm{~cm}^{3}$ & 150.53 & 97.47 & 112.62 & 120.20 & 111.60 & 91.19 & 98.84 & 100.57 \\
\hline Lithovit $0.5 \mathrm{~g} / \mathrm{l}$ & 70.68 & 25.32 & 53.40 & 49.80 & 73.87 & 21.81 & 45.55 & 47.08 \\
\hline Lithovit $1.0 \mathrm{~g} / \mathrm{l}$ & 76.81 & 37.10 & 58.37 & 57.43 & 76.33 & 29.14 & 68.41 & 57.96 \\
\hline Lithovit $1.5 \mathrm{~g} / \mathrm{l}$ & 88.70 & 52.27 & 78.21 & 73.06 & 91.40 & 36.33 & 79.15 & 68.96 \\
\hline Diatoms $100 \mathrm{~cm}^{3}+$ Kristalon $2 \mathrm{~g}$ & 137.70 & 87.72 & 99.17 & 108.20 & 119.35 & 104.86 & 102.14 & 108.78 \\
\hline Diatoms $100 \mathrm{~cm}^{3}+$ Lithovit $1.0 \mathrm{~g} / \mathrm{l}$ & 110.01 & 72.90 & 68.09 & 83.67 & 86.56 & 65.24 & 88.59 & 80.13 \\
\hline Mean a & 105.08 & 54.40 & 68.58 & & 93.88 & 47.95 & 69.31 & \\
\hline \multicolumn{9}{|l|}{ LSD at 0.05 for } \\
\hline Cultivars (a) & & & 4.73 & & & & 6.53 & \\
\hline Treatment (b) & & & 9.46 & & & & 13.07 & \\
\hline Interaction $(\mathbf{a} \times \mathbf{b})$ & & & 16.38 & & & & 22.36 & \\
\hline
\end{tabular}

and $100.57(\mathrm{~g})$, respectively. In contrast the lowest values were obtained as a result of untreated plants (control), giving 39.48 and $41.01 \mathrm{~g}$ in the first and second seasons, respectively. The interaction, cleared that, the highest records were obtained from supplying plants of Hibiscus cv. "San Diego" with Diatoms at $200 \mathrm{~cm}^{3} /$ pot in the first season and same cultivar applied with Diatoms at $200 \mathrm{~cm}^{3} /$ pot + Kristalon $(2 \mathrm{~g} / \mathrm{pot})$ in the second season, giving 150.53 and $119.35 \mathrm{~g}$, in the first and second season, respectively. Whereas the lowest fresh weight of roots were obtained from "Butterfly" cv. combined with control treatment in both seasons.

\section{Chemical Constituents}

Data exhibited in Tables 8, 9, 10 and 11 show the effect of different Hibiscus cultivars, fertilizations treatments and their interaction on chemical constituents in leaves in the second season.

\section{Total carbohydrates (\%)}

Data presented in Table 8 reveal the effect of different Hibiscus cultivars, fertilization treatments and their interaction on total carbohydrates percentage in leaves in the second season. The different Hibiscus cultivars slightly differed in their contents of total carbohydrates in leaves as indicated in Table 8. However, it could be mentioned that either Hibiscus cv. San Diego or Hibiscus cv. Peach Schnapps were obtained the highest total carbohydrates (\%) in leaves $(29.53$ and $28.11 \%$, respectively). Meanwhile, Hibiscus cv. Butterfly recorded the lowest mean in this concern $(26.05 \%)$. All fertilizer treatments caused an increment in total carbohydrates (\%) in leaves comparing with that recorded from untreated plants (control) as seen in Table 8 . However treating plants with the combination of Diatoms at $100 \mathrm{~cm}^{3}+$ Kristalon at $2 \mathrm{~g}$ was the best treatment used in raising total carbohydrates, followed in the second rank by 
Table 8. Effect of different Hibiscus rosa-sinensis cultivars, fertilizer treatments and their interaction on total carbohydrates (\%) in leaves in the second season (2014)

\begin{tabular}{|c|c|c|c|c|}
\hline Cultivars (a) & $\begin{array}{l}\text { Red flowers } \\
\text { (San Diego) }\end{array}$ & $\begin{array}{c}\text { Yellow flowers } \\
\text { (Butterfly) }\end{array}$ & $\begin{array}{c}\text { Orange flower } \\
\text { (Peach Schnapps) }\end{array}$ & $\begin{array}{c}\text { Mean } \\
\text { b }\end{array}$ \\
\hline$\overline{\text { Control }}$ & 21.72 & 16.24 & 19.38 & 19.11 \\
\hline Kristalon $1 \mathrm{~g}$ & 30.33 & 25.97 & 28.37 & 28.22 \\
\hline Kristalon 2 g & 31.93 & 28.41 & 30.48 & 30.27 \\
\hline Kristalon $4 \mathrm{~g}$ & 33.01 & 30.77 & 31.94 & 31.90 \\
\hline Diatoms $50 \mathrm{~cm}^{3}$ & 26.81 & 25.01 & 25.06 & 25.62 \\
\hline Diatoms $100 \mathrm{~cm}^{3}$ & 28.39 & 27.68 & 28.04 & 28.04 \\
\hline Diatoms $200 \mathrm{~cm}^{3}$ & 31.105 & 28.82 & 29.29 & 29.74 \\
\hline Lithovit $0.5 \mathrm{~g} / \mathrm{l}$ & 24.07 & 15.54 & 22.96 & 20.86 \\
\hline Lithovit $1.0 \mathrm{~g} / \mathrm{l}$ & 25.77 & 22.06 & 24.04 & 23.96 \\
\hline Lithovit $1.5 \mathrm{~g} / \mathrm{l}$ & 29.91 & 25.91 & 28.42 & 28.08 \\
\hline Diatoms $100 \mathrm{~cm} 3+$ Kristalon $2 \mathrm{~g}$ & 36.86 & 33.96 & 36.34 & 35.72 \\
\hline Diatoms $100 \mathrm{~cm} 3$ + Lithovit $1.0 \mathrm{~g} / \mathrm{l}$ & 34.48 & 32.30 & 33.13 & 33.30 \\
\hline Mean a & 29.53 & 26.05 & 28.11 & \\
\hline
\end{tabular}

plants received the combination of Diatoms at $100 \mathrm{~cm}^{3}+$ Lithovit at $1.0 \mathrm{~g} / 1$, whereas supplying plants with Kristalon at $4 \mathrm{~g} / 1$ occupied the third rank in raising the same constituent (35.72, 33.50 and $31.90 \%$, respectively). On the contrary, the lowest values were obtained as a result of untreated plants (control) and plants which received Lithovit at $0.5 \mathrm{~g} / 1$ recording (19.11 and 20.86\%, respectively). The other treatments gave an intermediate effects in this regard. Concerning the interaction, highest values were gained as a result of treating either Hibiscus cv. Peach Schnapps or Hibiscus cv. San Diego with either the combination of Diatoms at $100 \mathrm{~cm}^{3}+$ Kristalon at $2 \mathrm{~g} / 1$ or the combination of Diatoms at $100 \mathrm{~cm}^{3}+$ Lithovit at $1.0 \mathrm{~g} / 1$ as well as plants of Hibiscus cv. Butterfly which supplied with the combination of Diatoms at $100 \mathrm{~cm}^{3}+$ Kristalon at $2 \mathrm{~g} / 1$. These treatments registered $36.34,33.125,36.86,34.475$ and $33.96 \%$, respectively. In contrast the lowest values were obtained from plants of Hibiscus $\mathrm{cv}$. Butterfly which received Lithovit at $0.5 \mathrm{~g} / 1$ $(15.54 \%)$, as well as for untreated plants with fertilization of the three cultivars $(19.375,21.72$ and $16.24 \%$ for Peach Schnapps cv., San Diego cv. and Butterfly cv., respectively).

\section{Nitrogen (\%)}

Slight differences in N (\%) in leaves were observed among the different Hibiscus cultivars (Table 9). However, it could be mentioned that Peach Schnapps cultivar produced the highest N (\%) in leaves, followed by San Diego cultivar, which occupied the second rank, then came the Butterfly cultivar recording the lowest value in this regard. It is evident from data scored in Table 9 the clear increment in N (\%) in leaves due to treating plants with Diatoms at $200 \mathrm{~cm}^{3}$, or at $100 \mathrm{~cm}^{3}$, Kristalon at $4 \mathrm{~g} /$ pot and the combination of Diatoms at $100 \mathrm{~cm}^{3}+$ Kristalon at $2 \mathrm{~g} /$ pot, occupying the first, second, third and fourth ranks in raising $\mathrm{N}(\%)$ in leaves, registering 2.12, 2.07, 2.00 and $1.93 \%$, respectively. In contrast, the lowest values were a result of treating plants with Diatoms at 50 $\mathrm{cm}^{3}$, Lithovit at $1.0 \mathrm{~g} / 1$, Lithovit at $1.5 \mathrm{~g} / 1$ and the combination of Diatoms at $100 \mathrm{~cm}^{3}+$ Lithovit at $1.0 \mathrm{~g} / 1$ recording only $1.69,1.62$, 1.61 and $1.61 \%$, respectively. 
Table 9. Effect of different Hibiscus rosa-sinensis cultivars, fertilizer treatments and their interaction on $\mathbf{N}(\%)$ in leaves in the second season (2014)

\begin{tabular}{|c|c|c|c|c|}
\hline Cultivars (a) & $\begin{array}{l}\text { Red flowers } \\
\text { (San Diego) }\end{array}$ & $\begin{array}{c}\text { Yellow flowers } \\
\text { (Butterfly) }\end{array}$ & $\begin{array}{c}\text { Orange flowers } \\
\text { (Peach Schnapps) }\end{array}$ & $\begin{array}{c}\text { Mean } \\
\text { b }\end{array}$ \\
\hline$\overline{\text { Control }}$ & 1.96 & 1.48 & 2.10 & 1.84 \\
\hline Kristalon 1 g & 1.70 & 1.66 & 1.93 & 1.76 \\
\hline Kristalon 2 g & 1.61 & 1.82 & 1.91 & 1.78 \\
\hline Kristalon $4 \mathrm{~g}$ & 1.82 & 2.10 & 2.10 & 2.00 \\
\hline Diatoms $50 \mathrm{~cm}^{3}$ & 1.54 & 1.68 & 1.86 & 1.69 \\
\hline Diatoms $100 \mathrm{~cm}^{3}$ & 2.10 & 2.03 & 2.10 & 2.07 \\
\hline Diatoms $200 \mathrm{~cm}^{3}$ & 2.24 & 2.10 & 2.03 & 2.12 \\
\hline Lithovit $0.5 \mathrm{~g} / \mathrm{l}$ & 1.75 & 1.96 & 1.96 & 1.89 \\
\hline Lithovit $1.0 \mathrm{~g} / \mathbf{l}$ & 1.85 & 1.68 & 1.33 & 1.62 \\
\hline Lithovit $1.5 \mathrm{~g} / \mathrm{l}$ & 1.47 & 1.75 & 1.61 & 1.61 \\
\hline Diatoms $100 \mathrm{~cm}^{3}+$ Kristalon $2 \mathrm{~g}$ & 1.99 & 1.67 & 2.15 & 1.93 \\
\hline Diatoms $100 \mathrm{~cm}^{3}+$ Lithovit $1.0 \mathrm{~g} / \mathrm{l}$ & 1.77 & 1.26 & 1.81 & 1.61 \\
\hline Mean a & 1.82 & 1.77 & 1.91 & \\
\hline
\end{tabular}

\section{Phosphorus (\%)}

Slight differences in P (\%) in leaves were observed among the different Hibiscus cultivars (Table 10). However, it could be mentioned that Butterfly cultivar was the best in containing $\mathrm{P}$ (\%) in leaves, followed by Schnapps cultivar and then came San Diego cultivar $(0.39,0.37$ and $0.33 \%$, respectively). Supplying plants with Diatoms at $50 \mathrm{~cm}^{3}$, Diatoms at $200 \mathrm{~cm}^{3}$ and the combination of Diatoms at $100 \mathrm{~cm}^{3}+$ Kristalon at $2 \mathrm{~g} / \mathrm{l}$ caused a clear increment in P (\%) in leaves comparing with that gained from the other treatments used, giving $0.47,0.47$ and $0.45 \%$, respectively. In contrast, the lowest records were resulted from treating plants with Kristalon at either 1 or $2 \mathrm{~g}$, recording 0.25 and $0.29 \%$, respectively. The other treatments gave an intermediate effect in this concern. Regarding the interaction, the highest values of $\mathrm{P}(\%)$ in leaves were obtained as a result of receiving San Diego cv. either Diatoms at $50 \mathrm{~cm}^{3}$ or at 200 $\mathrm{cm}^{3}$, scoring 0.53 and $0.575 \%$, respectively. On the contrary, the lowest values were belongs to plants of Schnapps cv. which received Kristalon at $1 \mathrm{~g} /$ pot, plants of San Diego cv. which received Kristalon at 1 and $2 \mathrm{~g} /$ pot, as well as Lithovit at $1.0 \mathrm{~g} / \mathrm{l}$, registering $0.235,0.23,0.235$ and $0.225 \%$, respectively.

\section{Potassium (\%)}

The highest $\mathrm{K}(\%)$ in leaves was obtained by Hibiscus cv. Butterfly cultivar (Table 11). Meanwhile, the second rank was the content of Hibiscus cv. San Diego. The third rank was of Hibiscus cv. Peach Schnapps, scoring 2.20, 1.96 and $1.90 \%$, respectively. Supplying plants with Lithovit at $0.5,1.0$ and $1.5 \mathrm{~g} / 1$ and Kristalon at 4 $\mathrm{g} / \mathrm{l}$ gave the highest values of $\mathrm{K}(\%)$ in leaves, registering 2.16, 2.24, 2.13 and $2.10 \%$, respectively. In contrast, untreated plants with fertilization (control) or those which received the combination of Diatoms at $100 \mathrm{~cm}^{3}+$ Lithovit at $1.0 \mathrm{~g} / 1$ gave the lowest means in this respect, registering only 1.77 and $1.75 \%$, respectively. The other treatments revealed an intermediate effects in this concern. With regard to the interaction, data presented in Table 11 reveal the prevalence of Hibiscus cv. Butterfly which received Diatoms at $50 \mathrm{~cm}^{3}$, Lithovit at 
Table 10. Effect of different Hibiscus rosa-sinensis cultivars, fertilizer treatments and their interaction on $P(\%)$ in leaves in the second season (2014)

\begin{tabular}{|c|c|c|c|c|}
\hline Cultivars (a) & $\begin{array}{l}\text { Red flowers } \\
\text { (San Diego) }\end{array}$ & $\begin{array}{l}\text { Yellow flowers } \\
\text { (Butterfly) }\end{array}$ & $\begin{array}{c}\text { Orange flower } \\
\text { (Peach Schnapps) }\end{array}$ & $\begin{array}{c}\text { Mean } \\
\text { b }\end{array}$ \\
\hline Control & 0.275 & 0.465 & 0.485 & 0.41 \\
\hline Kristalon 1 g & 0.235 & 0.275 & 0.235 & 0.25 \\
\hline Kristalon 2 g & 0.23 & 0.285 & 0.355 & 0.29 \\
\hline Kristalon $4 \mathrm{~g}$ & 0.25 & 0.42 & 0.29 & 0.32 \\
\hline Diatoms $50 \mathrm{~cm}^{3}$ & 0.53 & 0.45 & 0.44 & 0.47 \\
\hline Diatoms $100 \mathrm{~cm}^{3}$ & 0.23 & 0.41 & 0.425 & 0.36 \\
\hline Diatoms $200 \mathrm{~cm}^{3}$ & 0.575 & 0.475 & 0.35 & 0.47 \\
\hline Lithovit $0.5 \mathrm{~g} / \mathrm{l}$ & 0.25 & 0.295 & 0.26 & 0.27 \\
\hline Lithovit $1.0 \mathrm{~g} / \mathbf{l}$ & 0.225 & 0.355 & 0.265 & 0.28 \\
\hline Lithovit $1.5 \mathrm{~g} / \mathbf{l}$ & 0.355 & 0.37 & 0.395 & 0.37 \\
\hline Diatoms $100 \mathrm{~cm}^{3}+$ Kristalon $2 \mathrm{~g}$ & 0.44 & 0.445 & 0.475 & 0.45 \\
\hline Diatoms $100 \mathrm{~cm}^{3}+$ Lithovit $1.0 \mathrm{~g} / \mathrm{l}$ & 0.4 & 0.415 & 0.435 & 0.42 \\
\hline Mean a & 0.33 & 0.39 & 0.37 & \\
\hline
\end{tabular}

Table 11. Effect of different Hibiscus rosa-sinensis cultivars, fertilizer treatments and their interaction on $\mathrm{K}(\%)$ in leaves in the second season (2014)

\begin{tabular}{|c|c|c|c|c|}
\hline Cultivars (a) & $\begin{array}{l}\text { Red flowers } \\
\text { (San diego) }\end{array}$ & $\begin{array}{c}\text { Yellow } \\
\text { flowers } \\
\text { (Butterfly) }\end{array}$ & $\begin{array}{c}\text { Orange } \\
\text { flower (Peach } \\
\text { Schnapps) }\end{array}$ & $\begin{array}{c}\text { Mean } \\
\text { b }\end{array}$ \\
\hline$\overline{\text { Control }}$ & 1.70 & 2.08 & 1.54 & 1.77 \\
\hline Kristalon $1 \mathrm{~g}$ & 2.10 & 2.20 & 1.71 & 2.00 \\
\hline Kristalon 2 g & 2.11 & 2.17 & 1.89 & 2.06 \\
\hline Kristalon $4 \mathrm{~g}$ & 2.00 & 2.26 & 2.05 & 2.10 \\
\hline Diatoms $50 \mathrm{~cm}^{3}$ & 1.95 & 2.38 & 1.64 & 1.99 \\
\hline Diatoms $100 \mathrm{~cm}^{3}$ & 2.07 & 2.23 & 1.78 & 2.02 \\
\hline Diatoms $200 \mathrm{~cm}^{3}$ & 1.95 & 2.10 & 1.96 & 2.00 \\
\hline Lithovit $0.5 \mathrm{~g} / \mathrm{l}$ & 2.14 & 2.24 & 2.11 & 2.16 \\
\hline Lithovit $1.0 \mathrm{~g} / \mathrm{l}$ & 2.02 & 2.38 & 2.32 & 2.24 \\
\hline Lithovit $1.5 \mathrm{~g} / \mathrm{l}$ & 1.98 & 2.44 & 1.98 & 2.13 \\
\hline Diatoms $100 \mathrm{~cm}^{3}+$ Kristalon $2 \mathrm{~g}$ & 1.92 & 2.03 & 2.2 & 2.05 \\
\hline Diatoms $100 \mathrm{~cm}^{3}+$ Lithovit $1.0 \mathrm{~g} / \mathrm{l}$ & 1.65 & 1.91 & 1.69 & 1.75 \\
\hline Mean a & 1.96 & 2.20 & 1.90 & \\
\hline
\end{tabular}


$1.0 \mathrm{~g} / \mathrm{l}$ and Lithovit at $1.5 \mathrm{~g} / \mathrm{l}$ in raising $\mathrm{K}(\%)$ in leaves, giving $2.38,2.38$ and $2.44 \%$, respectively. Meanwhile, the opposite was the right for plants of Hibiscus cv. Peach Schnapps untreated with fertilization or plants of Hibiscus cv. San Diego which supplied with the combination of Diatoms at $100 \mathrm{~cm}^{3}+$ Lithovit at $1.0 \mathrm{~g} / 1$ which recorded the lowest means in this concern (1.54 and $1.65 \%$, respectively).

The previous results indicated the prevalence of applying the different Kristalon levels in improving vegetative growth parameters as plant height, number of leaves/plant, number of branches/plant and fresh weight of vegetative growth. However, the great influence was obtained on plant traits due to supplying plants with Kristalon may be due to it contains macro and micro elements, especially, N,P and $\mathrm{K}$ elements which play a major role in growth and development of any plant, where $\mathrm{N}$ is a main constituents of all proteins and nucleic acids, besides involving $\mathrm{P}$ in energy transfer process and building of phospholipids and nucleic acids (Yeonhee et al. 2000). Meanwhile, potassium is a very effective macro element on growth and development of the different plants. Additionally, enhance translocation of sugar and carbohydrates through plant organs, increases protein synthesis and different metabolic processes (Csirzinsky, 1999). However, the superiority of applying Kristalon was also confirmed by a lot of scientists on plants. (Abou-Dahab, 1996) mentioned that Schefflera arboricola cv. Gold Capella plants were sprayed with Kristalon. Results revealed that Kristalon increased plant height, number of leaves and fresh weight of leaves (Saleh et al., 1998) on Ficus benjamina reported that the highest level of Kristalon (2 g/l) increased plant height, number of leaves/plant, branches number of plant, and fresh and dry weights of shoots. Mansour et al. (2015) on Gladiolus grandiflorus reported that using the lower Kristalon level (2 g) gave the tallest plants and the highest number of leaves per plant. Results also showed the effect of using Nano fertilizers, this might be due to an increase in nutrients use efficiency, reduce soil toxicity and minimize the potential negative effects associated with over dosage and reducing the frequency of the application (Naderi and Danesh-Shahraki, 2013). However, there are records of the beneficial effects of Lithovit on plant growth, (Nassef and Nabeel 2012) on broccoli cultivars and (Hanafey and Abd El-Rahman, 2014) on wheat genotyps. The improving of $\mathrm{N}, \mathrm{P}$ and $\mathrm{K}$ in plant tissues as a result of treating plants with Kristalon was also recorded with (Bazarra et al., 2012) on Gladiolus cv. Novalux.

\section{REFERENCES}

Abou-Dahab, T.A.M. (1996). Effect of growing media, nitrogen sources and commercial fertilizers on growth and chemical composition of Brassaia arboricola cv. "Gold Capelia" Plants. Ph. D. Thesis, Fac. Agric. Cairo Univ., Egypt.

Anil, K. and S. Ashatha (2012). Review on Hibiscus rosasinensis. Int. J. of Res. in Pharmaceutical and Biomedical Sci., 3 (2): $534-538$.

Aze El-Dean, H.A. and A.M. Hassan (2009). Effect of konetin and NPK fertilization on vegetative growth and chemical composition of Furcareafoetiola cv. Mediopicta, L. J. Biol. Chem. Environ. Sci., 4 (1): 695- 704.

Bazaraa, W.M., G.H. Abdel-Fattah and A. Nabih (2012). Effect of soil media, biostimulants and fertilization on corms and cormlets production and chemical constituents of Gladiolus cv. Novalux. Egypt. J. Hort., 39 (2):105-120.

Beinsan, C., R. Sumalan, S. Gadea and S. Vatca (2014). Physiological indicators study involved in productivity increasing in tomato. Pro. Environ., $7: 218$ - 224.

Csirzinsky, A.A. (1999). Yield response of herbs to $\mathrm{N}$ and $\mathrm{K}$ in sand in multiple harvests. J. Herbs. Spices and Medic. Plants, 6 (4): 11-22.

Hanafey, F.M. and L.A. Abd El-Rahman (2014). Inducing salinity tolerance in wheat plants by hydrogen peroxide and lithovit "a nano$\mathrm{CaCO}_{3}$ fertilizer". J. Agric. Res. Kafr ElSheikh Univ., 40 (4) : 696-719.

Herbert, D., J. Philipps and R. Strange (1971). Determination of total Carbohydrates . Meth. Microbiol., 58 : 209-344. 
Huysman, J.J., W. Vyverman and L. Veylder (2014). Molecular regulation of the diatom cell cycle. J. Experiment. Bot., 65 (10) : 2573-2584.

Jadhav, V.M., R.M. Thorat , V.J. Kadam and N.S. Sathe (2009). Traditional medicinal uses of Hibiscus rosa-sinensis. J. Pharm. Res., 2 (8): 1220-1222.

Kheder, H.M.A. (2010). Physiological studies on some indoor plants. M.Sc. Thesis, Fac. Agric., Kafer El-Sheikh Univ., Egypt.

Mansour, H.A., M.M.M. Hussein and S.A. Gomaa (2015). Response of Gladiolus grandiflorus cv. Peter Pears to different drip irrigation levels and kristalon treatments. J. Biol. Chem. Environ. Sci., 10 (2): 417-433.

Moisă, R. and V. Berar (2015). Study of the effect of several natural fertilizers on the seedlings leaf area for some tomato cultivars. J. Hort., Forestry and Biotechnol., 19 (2): $77-$ 81.

Naderi, M.R. and A. Danesh-Shahraki (2013). Nanofertilizers and their roles in sustainable agriculture. Int. J. Agri. Crop Sci. 5 (19): 2229-2232.

Nassef, D.M.T. and A.H.M. Nabeel (2012). Response of two broccoli cultivars to foliar application of Lithovit fertilizer under two planting methods. Assiut J. Agric. Sci., 43 (6): $27-45$.

Ozmen, A. (2010). Cytotoxicity of Hibiscus rosa-sinensis flower extract. Int. J. Cytology, Cytosystematics and Cytogenetics, 63 (2): 157-161.
Piper, C.S. (1947). Soil and Plant Analysis. Univ. of Adelaide, Adelaide, Australia, 258 275.

Pregle, F. (1945). Quantitative Organic MicroAnalysis. $4^{\text {th }}$ Ed., J. and A. Churchill, Ltd., London, 280.

Saleh, S.I., Y.A. Hossni and M.A. Darwish (1998). Effect of kristalon and ammonium nitrate on the growth and chemical composition of Ficus benjamina L. plants. Egypt. J. Hort., 25 (2):167-178.

Shabana, S., M.S. Muzammil and S. Parsana (2013). Silver nano scaffold formation by flowers of Hibiscus rosa sinensis. Int. J. Herbal Med., 1 (2): 169-174.

Snedecor, C.W. and W.G. Cochran (1972). Statistical Methods. $6^{\text {th }}$ Ed. Iowa State Univ., Press, Iowa, USA, 381.

Sukirti, U. and U. Prashant (2011). Hibiscus rosa-sinensis: Pharmacological review. Int. J. Res. Pharm. and Biomed. Sci., 2 (4): 14491450.

Troug, E. and A. Meyer (1939). Improvement in deiness colorimetric method for phosphorus and arsenic. Ind. Eng. Chem. Anal. Ed., 1: 136-139.

Yeonhee, C., P. Eueh and C. Mashee (2000). Effect of nitrogen from nutrient solution on the growth of Aster tataricus, Chrysanthemum boreale and Frafugium japonicum. Korean J. Horts. Sci. Tech., 18 (1): 14-17. 


\title{
تأثير أنواع مختلفة من التسميد علي الصفات المورفولوجية والمكونات الكيماوية لثلاثة أصناف من

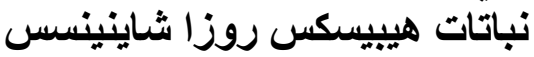

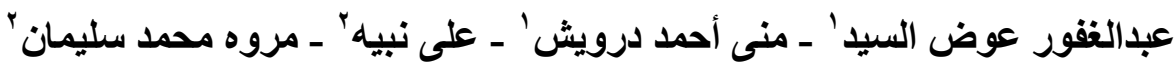 \\ ا ـ قسم الزينة ـ كلية الزر اعة ـ جامعة القاهرة ـ مصر \\ r ـ قسم بحوث الحدائق النباتية ـ معهد البساتين ـ مركز البحوث الزر اعية ـ الجيزة ـ مصر
}

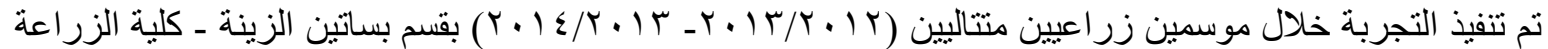

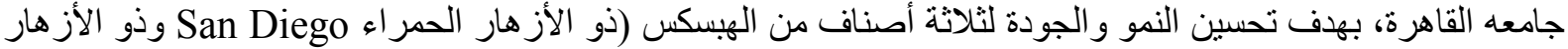

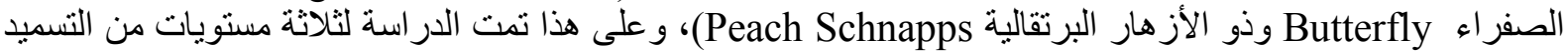

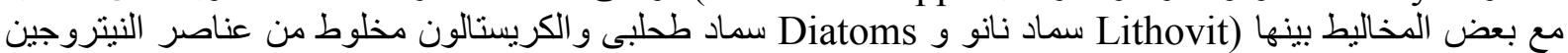
و الفوسفور و البوتاسيوم و العناصر الصغرى) علي الثلاثة أصناف فى كلا الموسمين، وقد أوضحت النقان النتائج تفوق الصنف San Diego

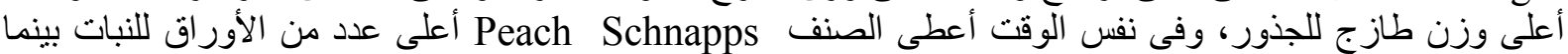

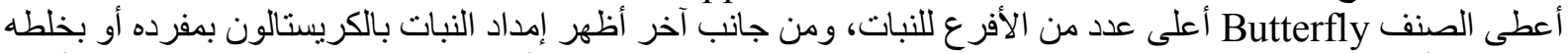

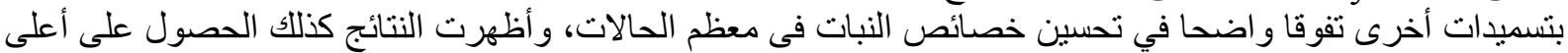

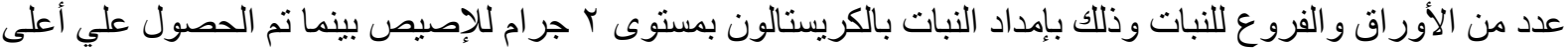

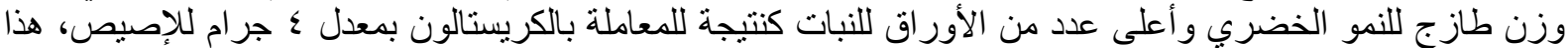

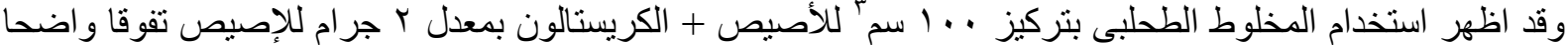



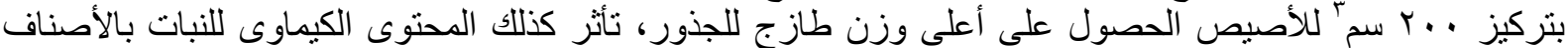

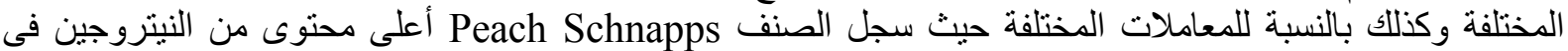

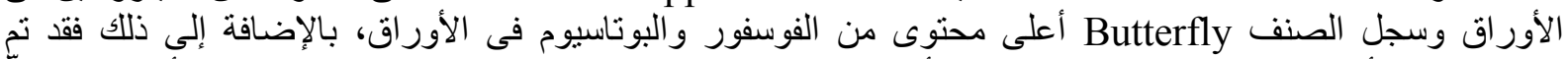

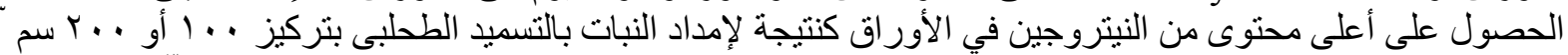

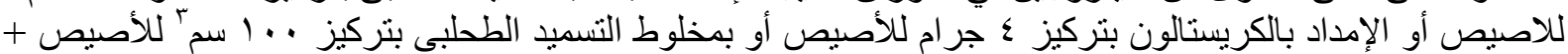

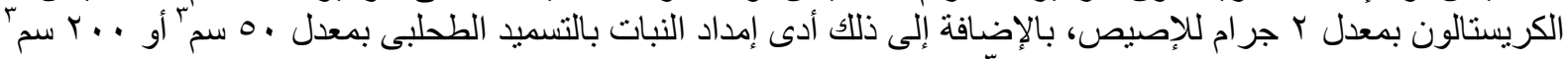

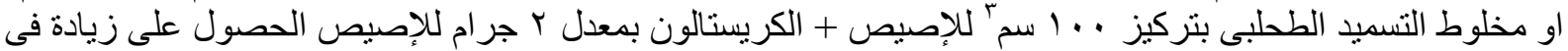

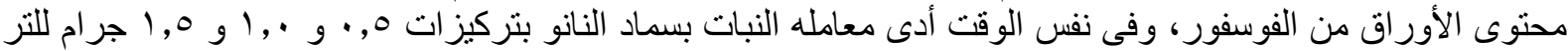

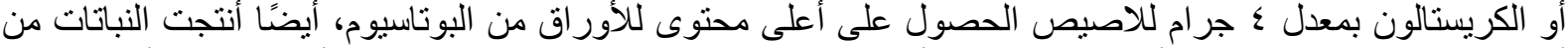

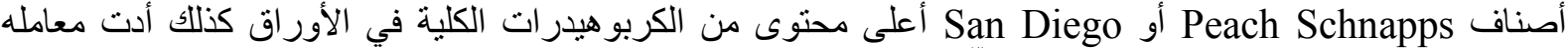

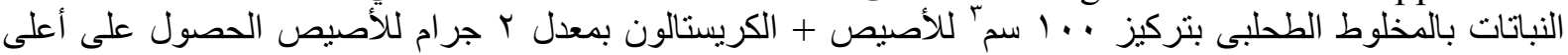

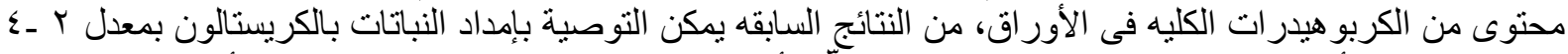

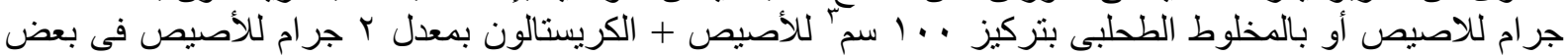
الحالات وذلك لتحقيق الهدف من إنتاج نباتات الهبسكس عالية الجودة.

أستاذ الزينة - كلية الزر اعة - جامعة القاهرة. أستاذ الزينة المتفرغ - كلية الزر اعة - جامعة الزقازيقة الزئة

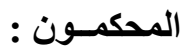

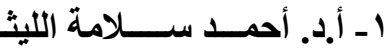

r أ أ.د. علي عبدالحميد علي معوض الئ 